\title{
Utilization of the Internet on Academic Information Systems IAIN Kendari
}

\author{
M.Amin, Ambar Sri Lestari \\ Islamic State Institute of Kendari (IAIN Kendari) \\ Southeast Sulawesi Indonesia
}

\begin{abstract}
This study discusses the internet which can be used to convey information quickly and widely through an online service that aims to determine the level of user assessments of the use of the Internet in support of academic activities and to obtain information difficulties or obstacles the use of internet in proses learning and teaching as well as the achievements of the increase in the number of students in education after using the internet at IAIN Kendari. The benefits of this research in order to sustain the intensity of management education in IAIN Kendari better, facilitate and expedite the learning activities in an effort to increase the productivity of education, and boosted achievement the number of students each year and can be used as one input to participate in providing facilities supporting the use of internet online services to support the academic activities in proses education. This type of research is mixed or mixed method research, data collection techniques used are questionnaires, interviews, observation and observation. This research is a field research (field research), the main source used is Kendari IAIN students who are still active in college and often use the internet, as well as other documents that support this research. The number of respondents of this study was 100 respondents to be sampled and analyzed using descriptive analysis. Interpretation of the data was based on the percentage of respondents. so the implementation of proses learning to use the internet in Kendari IAIN is needed. The review found that the use of the Internet is in the category very well and good for some applications services that are already online between $64 \%$ to $88 \%$, providing an assessment quite $11 \%$ to $28 \%$, and provide an assessment less category as much as $2 \%$ to $18 \%$. Constraints in the implementation of the development of learning to use the internet in the classroom IAIN Kendari is the Internet network access and the signal is very weak so that the implementation is not optimal for the development of learning. Internet use in IAIN Kendari implications for the achievement in publishing information that shows the plan can be achieved can be evidenced by the number of college students who choose IAIN Kendari every year increasing numbers who obtained the information from the website IAIN Kendari.
\end{abstract}

Keywords: Utilization of the Internet, Academic Information Systems, IAIN Kendari

\section{INTRODUCTION}

The system is a network of procedures that are interconnected, gathered together to perform an activity or to accomplish a particular goal (Jogiyanto, 2005). Another author said the system is an entity or a unit consisting of two or more components or subsystems (smaller systems) are interconnected and linked to achieve a goal. Other authors mention that a system can be defined as a collection or set of elements, components, or variables that organized, interact with each other, depend on each other, and integrated (Sutabri, 2012).

According to John W.Satzingeret in his book "System Analysis \& Design in Changging World 5th edition (2010)" explains that the system is a collection of related components that function together to get some results and information system is a collection of related components that 
gather processing, storage, and produces as output the information needed to complete business work. Academic information system is the software used to present information and organize the administration associated with academic activities. Academic Information System is a system that works for process data related to the academic in an institution education. In general, the data is processed in an information system academic among others include student data, teacher of data, data subjects, and other data that is internal based on the needs of each institution education. With the use of software as in this study is expected academic administrative activities can be well managed and the necessary information can be obtained easily and quickly.

\section{METHODOLOGY}

This study used mixed methods study is a product that is pragmatic and combine qualitative and quantitative approaches in the different stages of the research process (Abbas, 2010). But others argue that a mixed method research is a research method that combines or mengabungkan between quantitative and qualitative methods to be used together in a study, in order to obtain more comprehensive data, valid, reliable and objective (Sugiyono, 2012). This type of design using Sequential explanatory study is the first to use quantitative methods and the use of qualitative methods. The first phase, data collection and data analysis with quantitative, then the second stage of data collection and analysis of qualitative data, in order to strengthen the results of quantitative research conducted in the first phase (Creswell, 2009).

\section{RESULTS AND DISCUSSION \\ Assessment of Academic IAIN Internet Utilization Kendari \\ Analysis of Respondents Answers About SIA IAIN Kendari}

\begin{tabular}{|c|l|c|c|c|c|c|c|c|}
\hline \multirow{2}{*}{ No } & \multicolumn{1}{|c|}{ Statement } & \multicolumn{6}{|c|}{ Level Rating } \\
\cline { 2 - 8 } & $\begin{array}{l}\text { Very } \\
\text { good }\end{array}$ & Good & Enough & Less & $\begin{array}{c}\text { Less } \\
\text { Good }\end{array}$ & $\begin{array}{c}\text { Not } \\
\text { Good }\end{array}$ & Amount \\
\hline 1 & $\begin{array}{l}\text { Required } \\
\text { Academic } \\
\text { Information } \\
\text { System (AIS) to } \\
\text { look for } \\
\text { information }\end{array}$ & 34 & 35 & 11 & 2 & 0 & 18 & 100 \\
\hline$\%$ & $34 \%$ & $\%$ & $11 \%$ & $2 \%$ & $0 \%$ & $18 \%$ & $100 \%$ \\
\hline
\end{tabular}

Source of data: The results of the questionnaire distribution

Indicators are expressed on an overview assessment of the application SIA, based on the results of the analysis of the frequency distribution table can be seen that the students can use the Internet to obtain information, it can be seen from the 100 respondents, 34\% in the excellent category, $35 \%$ in both categories, and then as many as $11 \%$ in enough categories, $2 \%$ in the poor category and $18 \%$ did not answer. Based on the results of this research is that most students can take advantage of Internet media to obtain academic information by using access SIA IAN Kendari, this can be seen from the 100 respondents as many as $69 \%$ stated in the excellent category, and the category of good, so the information in a variety of types and in various forms can be communicated through the use of SIA IAIN Kendari. Based on interviews, it can be concluded that students IAIN Kendari use the Internet to obtain information that is very effective because the information obtained about the academic through the application of 
SIA as required, the Internet media covers a lot of sources of information up to date and covers all the basic aspects and aspects complementary means of support in the academic field IAIN Kendari. SIA is able to integrate the processes of academic administration into an information system capable of storing and processing the thousands of academic data from year to year systematically.

\begin{tabular}{|c|c|c|c|c|c|c|c|c|}
\hline \multirow{3}{*}{ No } & Respondents Ans & \multirow{2}{*}{\multicolumn{7}{|c|}{ Level Rating }} \\
\hline & \multirow{2}{*}{ Statement } & & & & & & & \\
\hline & & $\begin{array}{l}\text { Very } \\
\text { good }\end{array}$ & Good & Enough & Less & $\begin{array}{l}\text { Less } \\
\text { Good }\end{array}$ & $\begin{array}{c}\text { Not } \\
\text { Good }\end{array}$ & Amount \\
\hline 1 & $\begin{array}{l}\text { Login } \\
\text { Information } \\
\text { System Online } \\
\text { Services Main } \\
\text { IAIN Kendari }\end{array}$ & 20 & 44 & 19 & 8 & 2 & 7 & 100 \\
\hline$\%$ & & $20 \%$ & $44 \%$ & $19 \%$ & $8 \%$ & $2 \%$ & $7 \%$ & $100 \%$ \\
\hline
\end{tabular}

Source of data: The results of the questionnaire distribution

Based on the results of the frequency distribution can be seen that students often take advantage of the Internet media applications Login System IAIN Kendari, this can be seen from the 100 respondents were $20 \%$ in the excellent category, $44 \%$ in both categories, and then as much as $19 \%$ in the category enough, as much as $8 \%$ in the poor category, as much as $2 \%$ in the category is not well and as much as $7 \%$ had no preference. Based on the results of this research is that most college students often take advantage of the Internet media, this is reinforced by the results of the distribution of questionnaires circulated, can be seen from the 100 respondents, 64\% in the category of a very good and well, meaning more and more students are looking for information that is highly dependent on the connection internet, and want to get online services such as connect with IAIN Kendari Login System and in particular the latest news berhungan activities with academic information IAIN Kendari. Based on the findings and interviews from the above opinion can be interpreted, Kendari IAIN students take advantage of internet media for a variety of needs can be done wherever the user is located. The wide variety of online services application in the academic field of Internet media can assist students in education so that the students often take advantage of internet media as needed.

Analysis of Respondents Answers About Online Study Plan Card IAIN Kendari

\begin{tabular}{|c|c|c|c|c|c|c|c|c|}
\hline \multirow{2}{*}{ No } & \multicolumn{2}{|c|}{ Statement } & \multicolumn{7}{|c|}{ Level Rating } \\
\cline { 2 - 9 } & $\begin{array}{l}\text { Very } \\
\text { good }\end{array}$ & Good & Enough & Less & $\begin{array}{c}\text { Less } \\
\text { Good }\end{array}$ & $\begin{array}{c}\text { Not } \\
\text { Good }\end{array}$ & Amount \\
\hline 1 & $\begin{array}{l}\text { Required KRS } \\
\text { online } \\
\text { registration } \\
\text { system }\end{array}$ & 35 & 34 & 17 & 7 & 3 & 4 & 100 \\
\hline$\%$ & $35 \%$ & $34 \%$ & $17 \%$ & $7 \%$ & $3 \%$ & $4 \%$ & $100 \%$ \\
\hline
\end{tabular}

Source of data: The results of the questionnaire distribution 
Based on the results of the frequency distribution can be seen that students often take advantage of the Internet media applications KRS Online IAIN Kendari, this can be seen from the 100 respondents, 35\% in the excellent category, 34\% in both categories, and then as much as $17 \%$ in the category enough, as much as $7 \%$ in the poor category, as much as $3 \%$ in the category is not well and as much as $4 \%$ had no preference. Based on the results of this research is that the majority of Kendari IAIN students often take advantage of internet media, this is reinforced by the distribution of a questionnaire which can be seen from 100 respondents in $79 \%$ in the category of very good and excellent. Can be seen to this now that more and more students are very dependent with an internet connection. Based on the findings and interviews from the above opinion can be interpreted, Kendari IAIN students take advantage of internet media for a variety of needs. Cards including study plan by the beginning of the semester to register by using the online KRS application, the diversity of application of the internet media helps the students so that the students often take advantage of internet media as needed.

Analysis of Respondents Answers About Online Card Study Results IAIN Kendari

\begin{tabular}{|c|c|c|c|c|c|c|c|c|}
\hline \multirow[b]{2}{*}{ No } & \multirow[b]{2}{*}{ Statement } & \multicolumn{7}{|c|}{ Level Rating } \\
\hline & & $\begin{array}{l}\text { Very } \\
\text { good }\end{array}$ & Good & $\begin{array}{c}\text { Enou } \\
\text { gh }\end{array}$ & Less & $\begin{array}{l}\text { Less } \\
\text { Good }\end{array}$ & $\begin{array}{c}\text { Not } \\
\text { Good }\end{array}$ & Amount \\
\hline 1 & $\begin{array}{lr}\text { KHS online } \\
\text { information Test } \\
\text { Scores }\end{array}$ & 39 & 35 & 14 & 5 & 2 & 5 & 100 \\
\hline$\%$ & & $39 \%$ & $35 \%$ & $14 \%$ & $5 \%$ & $2 \%$ & $5 \%$ & $100 \%$ \\
\hline
\end{tabular}

Source of data: The results of the questionnaire distribution

Indicators are expressed about the application of KHS, based on the results of the analysis of the frequency distribution table can be seen that the students can use the Internet to obtain KHS, this can be seen from the 100 respondents as much as 39\% in the excellent category, 35\% in both categories, and then as much as $14 \%$ in the category of pretty, $7 \%$ in the unfavorable category, and 5\% did not answer. Based on the analysis and review of the above as well as the interviews conducted, it can be concluded that students IAIN Kendari use the Internet to obtain the card results of a study (KHS) through the application of KHS Online, wherever located may diupdet and via the Internet can be used to determine the value of the test results.

Analysis Respondents Answer Student Transcript IAIN Kendari

\begin{tabular}{|c|c|c|c|c|c|c|c|c|}
\hline \multirow{2}{*}{ No } & \multirow{2}{*}{ Statement } & \multicolumn{7}{|c|}{ Level Rating } \\
\cline { 2 - 9 } & $\begin{array}{c}\text { Very } \\
\text { good }\end{array}$ & Good & $\begin{array}{c}\text { Enou } \\
\text { gh }\end{array}$ & Less & $\begin{array}{c}\text { Less } \\
\text { Good }\end{array}$ & $\begin{array}{c}\text { Not } \\
\text { Good }\end{array}$ & Amount \\
\hline 1 & $\begin{array}{l}\text { Required Student } \\
\text { Transcript Online }\end{array}$ & 43 & 35 & 11 & 2 & - & 9 & 100 \\
\hline$\%$ & & $43 \%$ & $35 \%$ & $11 \%$ & $2 \%$ & - & $9 \%$ & $100 \%$ \\
\hline
\end{tabular}

Source of data: The results of the questionnaire distribution 
Frequency in the use of internet by the respondent, the indicator is expressed about the application of transcripts, based on the results of the analysis of the frequency distribution table can be seen that the students can use the Internet to obtain transkrif value, it can be seen from the 100 respondents, $43 \%$ in the excellent category, $35 \%$ in both categories, and then as much as $11 \%$ in enough categories, $2 \%$ in the unfavorable category, and $9 \%$ did not answer.

Based on the results of this research is that students can take advantage of Internet media to obtain Transkrif Value of Students, the Internet is a computer network that is capable of connecting computers in different places that have the Internet, so the information in various types and in various forms can be communicated, especially to obtain transkrif value IAIN students Kendari. Based on the analysis and review of the above as well as interviews of students it can be concluded that students IAIN Kendari use the Internet to obtain Transkrif Value Students through the application of SIA Online, the Internet media covers a lot of resources that can be used for needs and covers all the basic aspects and aspects of complementary in education easier and more effective to obtain it.

Analysis of Respondents Answers Regarding Online Fee Payment

\begin{tabular}{|c|c|c|c|c|c|c|c|c|}
\hline \multirow{2}{*}{ No } & \multirow{2}{*}{ Statement } & \multicolumn{7}{|c|}{ Level Rating } \\
\cline { 2 - 9 } & $\begin{array}{c}\text { Very } \\
\text { good }\end{array}$ & Good & Enough & Less & $\begin{array}{c}\text { Less } \\
\text { Good }\end{array}$ & $\begin{array}{c}\text { Not } \\
\text { Good }\end{array}$ & Amount \\
\hline $\begin{array}{l}\text { Payment of } \\
\text { fees online }\end{array}$ & 34 & 32 & 20 & 9 & - & 5 & 100 \\
\hline$\%$ & & $34 \%$ & $32 \%$ & $20 \%$ & $9 \%$ & - & $5 \%$ & $100 \%$ \\
\hline
\end{tabular}

Source of data: The results of the questionnaire distribution

Indicators are expressed about the application of payment of fees IAIN Kendari, based on the results of the analysis of the frequency distribution table can be seen that the students can use the Internet to payment of fees Online IAIN Kendari, this can be seen from the 100 respondents, $34 \%$ in the excellent category, $32 \%$ in category well, then as much as $20 \%$ in fair category, $9 \%$ in the unfavorable category, and $5 \%$ did not answer. Based on the results of this research is that students can take advantage of Internet media to do pembanyaran with the online system at the Bank who has worked with IAIN Kendari, the Internet is a computer network that is capable of connecting the computer where we are with a network the Internet, so the information in a variety of types and in various forms can be communicated. Based on the analysis and review of the above as well as interviews it can be concluded that students IAIN Kendari use the Internet to do pembanyaran with the online system at the Bank who has worked with IAIN Kendari, internet media covers a lot of resources that can be utilized and covers all the basic aspects and aspects complementary in the field of education. 
Analysis of Respondents Answers Regarding Admissions Online

\begin{tabular}{|c|c|c|c|c|c|c|c|c|}
\hline \multirow{2}{*}{ No } & \multicolumn{2}{|c|}{ Statement } & \multicolumn{7}{|c|}{ Level Rating } \\
\cline { 3 - 9 } & $\begin{array}{c}\text { Very } \\
\text { good }\end{array}$ & Good & $\begin{array}{c}\text { Enou } \\
\text { gh }\end{array}$ & Less & $\begin{array}{c}\text { Less } \\
\text { Good }\end{array}$ & $\begin{array}{c}\text { Not } \\
\text { Good }\end{array}$ & $\begin{array}{c}\text { Amo } \\
\text { unt }\end{array}$ \\
\hline 1 & $\begin{array}{l}\text { Information about the } \\
\text { admission of new } \\
\text { students (PMB) online }\end{array}$ & 36 & 46 & 11 & 4 & - & 3 & 100 \\
\hline$\%$ & & $36 \%$ & $46 \%$ & $11 \%$ & $4 \%$ & - & $3 \%$ & $100 \%$ \\
\hline
\end{tabular}

Source of data: The results of the questionnaire distribution

Indicators are expressed on Admissions Online IAIN Kendari, based on the results of the analysis of the frequency distribution table can be seen that the students can use the Internet for admissions online, it can be seen from the 100 respondents, 36\% in the excellent category, $46 \%$ in both categories, then as much as $11 \%$ in the category enough, $4 \%$ in the unfavorable category, and 3\% did not answer. Based on the results of this research is that most students can use the media for Admissions Online. Internet network is a computer network that is capable of connecting computers around the world that has internet connection, so the information in various types and in various forms can be communicated instantly and globally. The presence of the Internet has made it easier directly against the registration of distance. Through the Internet, anyone can access to obtain information that is needed in any needs more effectively. Based on the analysis and review of the above as well as interviews it can be concluded that students IAIN Kendari use the Internet for admission online through the application of new student enrollment, the Internet media covers a lot of sources of information up to date and covers all the basic aspects and aspects of complement in the field of education.

Respondents Answers Regarding Analysis Applications in E-Library

\begin{tabular}{|c|l|c|c|c|c|c|c|c|}
\hline \multirow{2}{*}{ No } & \multicolumn{2}{|c|}{ Statement } & \multicolumn{7}{|c|}{ Level Rating } \\
\cline { 3 - 9 } & $\begin{array}{c}\text { Very } \\
\text { good }\end{array}$ & Good & $\begin{array}{c}\text { Enou } \\
\text { gh }\end{array}$ & Less & $\begin{array}{c}\text { Less } \\
\text { Good }\end{array}$ & $\begin{array}{c}\text { Not } \\
\text { Good }\end{array}$ & $\begin{array}{c}\text { Amo } \\
\text { unt }\end{array}$ \\
\hline 1 & $\begin{array}{l}\text { Website e-libraries } \\
\text { needed for learning is } \\
\text { the application of digital } \\
\text { library }\end{array}$ & 9 & 34 & 28 & 23 & - & 6 & 100 \\
\hline$\%$ & & $9 \%$ & $34 \%$ & $28 \%$ & $23 \%$ & - & $6 \%$ & $100 \%$ \\
\hline
\end{tabular}

Source of data: The results of the questionnaire distribution

Based on the results of the frequency distribution can be seen that students often take advantage of the Internet media applications E-Library IAIN Kendari, this can be seen from the 100 respondents as much as $9 \%$ in the excellent category, 34\% in both categories, and then as much as $28 \%$ in the category enough, as much as $23 \%$ in the unfavorable category, and as much as $6 \%$ had no preference. Based on the results of this research is that most students want to take advantage of Internet media applications E-Library, this is reinforced by the results seberan questionnaire that was circulated, can be seen from the 100 respondents, $43 \%$ in the category of very good and good, then as much as $28 \%$ in the category enough and $29 \%$ said it was not good, hesitated and did not vote. More and more students look for and receive services 
through the application of E-Libraries are very dependent with internet connection, which is connected with the study or to locate the latest information on available literature in the library. Based on the findings and interviews from the above opinion can be interpreted, that the Kendari IAIN students take advantage of internet media for a variety of needs, particularly used for learning needs to find a book or literature.

Analysis of Respondents Answers Regarding Applications in E- Journal

\begin{tabular}{|c|c|c|c|c|c|c|c|c|}
\hline \multirow[b]{2}{*}{ No } & \multirow[b]{2}{*}{ Statement } & \multicolumn{7}{|c|}{ Level Rating } \\
\hline & & $\begin{array}{l}\text { Very } \\
\text { good }\end{array}$ & Good & $\begin{array}{c}\text { Enou } \\
\text { gh }\end{array}$ & Less & $\begin{array}{c}\text { Less } \\
\text { Good }\end{array}$ & $\begin{array}{l}\text { Not } \\
\text { Good }\end{array}$ & Amount \\
\hline 1 & $\begin{array}{l}\text { Website e-Journal } \\
\text { needed for learning } \\
\text { is IAIN Journal } \\
\text { Kendari }\end{array}$ & 13 & 32 & 28 & 16 & - & 11 & 100 \\
\hline$\%$ & & $13 \%$ & $32 \%$ & $28 \%$ & $16 \%$ & - & $11 \%$ & $100 \%$ \\
\hline
\end{tabular}

Source of data: The results of the questionnaire distribution

Based on the results of the frequency distribution can be seen that the students wanted to be published in the Journal E- applications, this can be seen from the 100 respondents, $13 \%$ stated in the excellent category, $32 \%$ in both categories, and then as much as $28 \%$ in the category enough, as much as $11 \%$ in the unfavorable category, and as many as $11 \%$ had no preference. Based on the results of this research is that most students want the results of the study, the journal can upload or publish on the Internet, this is reinforced by the results seberan questionnaire that was circulated, can be seen from the 100 respondents, $13 \%$ in the category of excellent, $32 \%$ good category, and enough $28 \%$, as much as $16 \%$ in the unfavorable category, and $11 \%$ did not choose this means more and more people want to get information E-Journal for the needs of research and assignments. Based on the findings and interviews from the above opinion can be interpreted, Kendari IAIN students want references, journals, and research results can be published via E- Journals IAIN Kendari applications for various needs in helping to complete the study so that students want to be able to utilize and take very good and either to look for references from E- Journals.

Analysis of Respondents Answers Regarding E-Learning Applications

\begin{tabular}{|c|c|c|c|c|c|c|c|}
\hline \multirow{2}{*}{ No } & \multicolumn{2}{|c|}{ Statement } & \multicolumn{6}{|c|}{ Level Rating } \\
\cline { 3 - 8 } & $\begin{array}{c}\text { Very } \\
\text { good }\end{array}$ & Good & Enough & Less & $\begin{array}{c}\text { Less } \\
\text { Good }\end{array}$ & Amount \\
\hline 1 & $\begin{array}{l}\text { Website E-learning } \\
\text { is the need of } \\
\text { students in online } \\
\text { learning }\end{array}$ & 23 & 36 & 15 & 17 & 9 & 100 \\
\hline$\%$ & & $23 \%$ & $36 \%$ & $15 \%$ & $17 \%$ & $9 \%$ & $100 \%$ \\
\hline
\end{tabular}

Source of data: The results of the questionnaire distribution 
Indicators are expressed about the benefits of the Internet, based on the results table of frequency distribution can be seen that the students helped with the internet applications vary, it can be seen from the 100 respondents, $23 \%$ in the excellent category, $36 \%$ in both categories, and then as much as $15 \%$ in the category enough, as much as $17 \%$ in the unfavorable category and as much as $9 \%$ said bad or doubtful. Based on the results of this research is that most college students often take advantage of the Internet media, this is reinforced by the results seberan questionnaire that was circulated, can be seen from the 100 respondents, $74 \%$ in the category of excellent, good, and pretty, as much as $26 \%$ in the unfavorable category, and bad. Utilization of the Internet media by students, over the web, the learning process can be done dynamically and does not depend on the time and space to study can be done through e-learning. Kendari IAIN students can access e-learning that can be done online, anywhere can be accessed over the mobile internet connection both for lessons and books are aired by the media. It can be concluded from the results of the research findings and the results of interviews of opinion over the interpretation, that Kendari IAIN students take advantage of internet media to the learning needs of the E-Learning method with all the advantages already can be learned and many enthusiasts with this method. Internet use most students often find it in peroses education by sharing knowledge with a variety of benefits on internet media, so students often take advantage of internet media as needed for the lesson material.

Analysis of Respondents Answers Regarding the E-mail Application

\begin{tabular}{|c|c|c|c|c|c|c|c|}
\hline \multirow{2}{*}{ No } & \multicolumn{2}{|c|}{ Statement } & \multicolumn{5}{c|}{ Level Rating } \\
\cline { 4 - 8 } & $\begin{array}{c}\text { Very } \\
\text { good }\end{array}$ & Good & $\begin{array}{c}\text { Enou } \\
\text { gh }\end{array}$ & Less & $\begin{array}{c}\text { Less } \\
\text { Good }\end{array}$ & Amount \\
\hline 1. & $\begin{array}{l}\text { Learning to use e-mail indicating } \\
\text { IAIN Kendari education has } \\
\text { adapted with the times }\end{array}$ & 55 & 28 & 11 & 6 & - & 100 \\
\hline$\%$ & & $55 \%$ & $28 \%$ & $11 \%$ & $6 \%$ & $0 \%$ & $100 \%$ \\
\hline
\end{tabular}

Source of data: The results of the questionnaire distribution

Based on the results of the frequency distribution can be seen that students often take advantage of internet media in the E-mail, it can be seen from the 100 respondents by $55 \%$ in the excellent category, $28 \%$ in both categories, and then as much as $11 \%$ in the category enough, as much as $6 \%$ in the unfavorable category. Based on the results of this research is that most college students often use e-mail, this is reinforced by the results of a questionnaire circulated seberan, can be seen from the 100 respondents as much as $83 \%$ in the category of excellent and good categories. While as many as $11 \%$ enough category, and $6 \%$ unfavorable. Utilization E-mail is one of the applications most used internet in terms of correspondence. This is because e-mail is a communication tool that is cheap, fast, and efficient. a very fast time and cost. E-mail sent will reach the addressee instantaneous e-mail is sent. Based on the research findings and the results of interviews of opinions on the above it can be concluded that students IAIN Kendari use the media for a variety of needs for more effective, efficient and cheap, just over an Internet connection and e-mail addresses, shipping will quickly get to the destination address and do not have to cost a fortune. 
Respondents Answers Regarding Analysis Applications in Blog

\begin{tabular}{|c|c|c|c|c|c|c|c|}
\hline \multirow{2}{*}{ No } & \multicolumn{2}{|c|}{ Statement } & \multicolumn{6}{|c|}{ Level rating } \\
\cline { 3 - 8 } & $\begin{array}{c}\text { Very } \\
\text { good }\end{array}$ & Good & Enough & Less & $\begin{array}{c}\text { Less } \\
\text { Good }\end{array}$ & $\begin{array}{c}\text { Amoun } \\
\mathrm{t}\end{array}$ \\
\hline 1 & $\begin{array}{l}\text { Development of } \\
\text { learning using blogs to } \\
\text { increase knowledge }\end{array}$ & 55 & 28 & 11 & 6 & - & 100 \\
\hline$\%$ & & $55 \%$ & $28 \%$ & $11 \%$ & $6 \%$ & $0 \%$ & $100 \%$ \\
\hline
\end{tabular}

Source of data: The results of the questionnaire distribution

Based on the results of the frequency distribution can be seen that students often take advantage of the Internet media applications in Blog, it can be seen from the 100 respondents by $55 \%$ in the excellent category, $28 \%$ in both categories, and then as much as $11 \%$ in the category enough, and as much as $6 \%$ in the unfavorable category. Based on the results of this research is that most college students often take advantage of the Internet media, this is reinforced by the results seberan questionnaire that was circulated, this can be seen from the 100 respondents as much as $83 \%$ in the excellent category, and the category of good, as much as $17 \%$ in the category enough and not good. Based on the findings and interviews from the above opinion can be concluded that students IAIN Kendari use the media for various needs in the development of learning blog application can be useful to increase knowledge, share resources among peers, cooperation and the opportunity to publish information directly, as well as participate in forums -forum locally and internationally.

\section{IAIN Difficulties Utilization of the Internet in Kendari}

Analysis of Respondents Answers Regarding Access to Technology in the Classroom Using Campus Facilities

\begin{tabular}{|c|c|c|c|c|c|c|}
\hline \multirow{2}{*}{1.} & \multirow{2}{*}{ Criteria } & \multicolumn{4}{|c|}{ Level Rating } & \multirow{2}{*}{$\begin{array}{ll}\text { 3. } & \text { Averag } \\
\text { e } \%\end{array}$} \\
\hline & & $\begin{array}{ll}4 . & 1\end{array}$ & 5. 2 & 6. 3 & 7. 4 & \\
\hline 8. & $\begin{array}{l}\text { Very } \\
\text { Good }\end{array}$ & $\begin{array}{ll}9 . & 6 \\
& \%\end{array}$ & $2 \%$ & $2 \%$ & $5 \%$ & $3,75 \%$ \\
\hline 10. & Good & $26 \%$ & $14 \%$ & $25 \%$ & $20 \%$ & $21,25 \%$ \\
\hline 11. & Enough & $23 \%$ & $34 \%$ & $30 \%$ & $33 \%$ & $30 \%$ \\
\hline 12. & Less Good & $25 \%$ & $33 \%$ & $33 \%$ & $28 \%$ & $29,75 \%$ \\
\hline 13. & Not Good & $6 \%$ & $14 \%$ & $8 \%$ & $10 \%$ & $9,5 \%$ \\
\hline 14. & $\begin{array}{l}\text { No } \\
\text { Answer }\end{array}$ & $14 \%$ & $3 \%$ & $2 \%$ & $4 \%$ & $5,75 \%$ \\
\hline
\end{tabular}

Source of data: The results of the questionnaire distribution

Based on the analysis of access to Internet technology in the classroom using campus facilities at the speed indicator / ease of access iternet in the update, download and upload in the classroom campus IAIN Kendari showed that 100 respondents as much as $3.75 \%$ in the excellent category, $21,25 \%$ in both categories, as much as $30 \%$ in the category enough, then as much as $29.75 \%$ in the unfavorable category, $9.5 \%$ in the category of poor and as much as $5.75 \%$ Undecided or not answered. Based on the results of this research is that most college students often take advantage of internet media in the classroom, this is reinforced by the results seberan questionnaire that was circulated, it can be seen from the 100 respondents as much as $25 \%$ in the excellent category, and the category of good, as much as $30 \%$ in the 
category enough. A total of $39.25 \%$ in the unfavorable category and bad. A higher level of assessment is less good and bad category.

Means the existing internet facilities often can not be used or used optimally due can be seen from the often wear as many as $39,25 \%$ in the category of very frequently accessed but not functioning well or badly. Based on research and interviews conducted can be concluded that the majority of students who have never felt the internet facilities that are in Kendari IAIN campus classes sometimes have trouble so it can not be used optimally this is reinforced by the statement; Internet weaknesses such as: (1) dependence on the Internet network and the signal is very weak; (2) The speed / ease of internet access in the update, download and upload at the time of loading sometimes misfire.

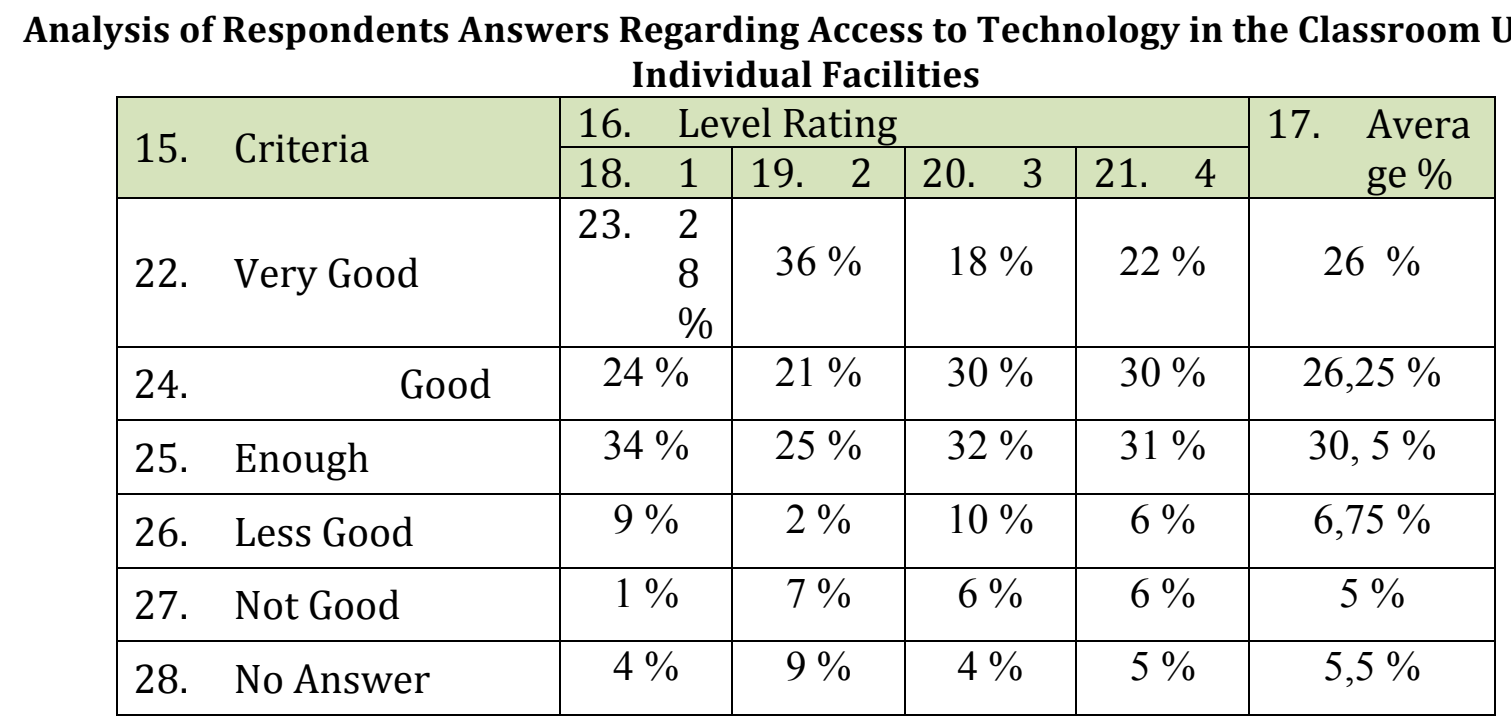

Source of data: The results of the questionnaire distribution

Based on the analysis of access to Internet technology in the classroom using its own facilities at the speed indicator / ease of access iternet in the update, download and upload in the classroom IAIN Kendari showed that 100 respondents, $26 \%$ in the excellent category, as much as $26.25 \%$ in both categories, as much as $30.5 \%$ in the category enough, then as much as $6.75 \%$ in the unfavorable category, as much as 5\% in the category of bad and 5.5\% did not answer or hesitation. Based on the results of this research is that most college students often take advantage of internet media in the classroom, this is reinforced by the results of a questionnaire circulated seberan, can be seen as many as 52 of the 100 respondents, $25 \%$ in the excellent category, and the category of good, as much as $30.5 \%$ in the category enough. A total of $6.75 \%$ in the unfavorable category, $5 \%$ poor category and $5.5 \%$ had no preference or hesitation.

Means the internet facility in the class campus IAIN Kendari uneven, it can be seen from the distribution of respondents who frequently use the Internet in the classroom campus IAIN Kendari, stating instead resulting from service Content Provider as much as $52.25 \%$ in the category of utilization is very good, and well, as much as $30.5 \%$ in the category simply by using its own facilities in the classroom. This means access to the internet with their own facilities can show as much as $82.75 \%$ of Internet access that can be utilized but the use of campus facilities can not be used to their fullest partly due to internal technical factors. Based on research and interviews conducted can be concluded that the majority of students who want to use the internet facility in Kendari IAIN campus classes can not be used up this is reinforced by 
the statement on the questionnaire; Internet weaknesses such as: (1) dependence on the Internet network and the signal is very weak; (2) Internet access in the classroom campus IAIN Kendari some were without signals have difficulty when it is needed as a support in learning.

\section{Achievement Utilization of the Internet in IAIN Kendari}

Analysis of Respondents Answers About Resources

\begin{tabular}{|c|c|c|c|c|c|c|c|c|}
\hline \multirow[b]{2}{*}{ No } & \multirow[b]{2}{*}{ Statement } & \multicolumn{7}{|c|}{ Level Rating } \\
\hline & & $\begin{array}{l}\text { Very } \\
\text { good }\end{array}$ & Good & Enough & $\begin{array}{c}\text { Les } \\
\mathrm{s}\end{array}$ & $\begin{array}{l}\text { Less } \\
\text { Good }\end{array}$ & $\begin{array}{l}\text { No } \\
\text { Good }\end{array}$ & Amount \\
\hline 1 & $\begin{array}{l}\text { Internet as a means of looking } \\
\text { resources development progress } \\
\text { of educational institutions }\end{array}$ & $41 \%$ & $49 \%$ & $8 \%$ & $2 \%$ & - & - & $100 \%$ \\
\hline 2 & $\begin{array}{l}\text { Sources of information on the } \\
\text { internet is an option of } \\
\text { prospective students to choose } \\
\text { educational institutions }\end{array}$ & $22 \%$ & $49 \%$ & $15 \%$ & $6 \%$ & - & $8 \%$ & $100 \%$ \\
\hline 3 & $\begin{array}{l}\text { Sources of information from the } \\
\text { Internet that attract capable of } \\
\text { providing the competitiveness } \\
\text { with other educational } \\
\text { institutions }\end{array}$ & $35 \%$ & $46 \%$ & $11 \%$ & $5 \%$ & - & $3 \%$ & $100 \%$ \\
\hline 4 & $\begin{array}{l}\text { Information about Kendari IAIN } \\
\text { can be accessed via the Internet } \\
\text { World Wide Web }\end{array}$ & $40 \%$ & $37 \%$ & $15 \%$ & $5 \%$ & - & $3 \%$ & $100 \%$ \\
\hline 5 & $\begin{array}{l}\text { Web IAIN provide complete } \\
\text { Kendari }\end{array}$ & $20 \%$ & $31 \%$ & $34 \%$ & $\begin{array}{l}11 \\
\%\end{array}$ & - & $4 \%$ & $100 \%$ \\
\hline 6 & $\begin{array}{l}\text { Forms of information system } \\
\text { services via the WWW is the } \\
\text { main service }\end{array}$ & $20 \%$ & $34 \%$ & $19 \%$ & $\begin{array}{l}11 \\
\%\end{array}$ & - & $16 \%$ & $100 \%$ \\
\hline$\%$ & & $29,67 \%$ & $41 \%$ & $17 \%$ & $\begin{array}{c}6,67 \\
\%\end{array}$ & $\%$ & $\begin{array}{c}5,66 \\
\%\end{array}$ & $100 \%$ \\
\hline
\end{tabular}

\section{Source of data: The results of the questionnaire distribution}

Analysis of Resources Answers of Respondents

\begin{tabular}{|c|c|c|c|c|c|c|c|c|}
\hline \multirow{2}{*}{29.} & \multirow{2}{*}{ Criteria } & \multicolumn{6}{|c|}{ 30. Level Rating } & \multirow{2}{*}{$\begin{array}{ll}\text { 31. Average } \\
\%\end{array}$} \\
\hline & & 32. 1 & 33. 2 & 34. 3 & 35. 4 & 36. 5 & 37. 6 & \\
\hline 38. & Very Good & $\begin{array}{ll}39 . & 41 \\
& \%\end{array}$ & $22 \%$ & $35 \%$ & $40 \%$ & $20 \%$ & $20 \%$ & $29,67 \%$ \\
\hline 40. & Good & $49 \%$ & $49 \%$ & $46 \%$ & $37 \%$ & $31 \%$ & $34 \%$ & $41 \%$ \\
\hline 41. & Enough & $8 \%$ & $15 \%$ & $11 \%$ & $15 \%$ & $34 \%$ & $19 \%$ & $17 \%$ \\
\hline 42. & Less Good & $2 \%$ & $5 \%$ & $5 \%$ & $5 \%$ & $10 \%$ & $9 \%$ & $6,67 \%$ \\
\hline 43. & Not Good & - & - & - & - & - & - & $\%$ \\
\hline 44. & $\begin{array}{l}\text { No } \\
\text { Answer }\end{array}$ & - & $8 \%$ & $3 \%$ & $3 \%$ & $4 \%$ & $16 \%$ & $5,66 \%$ \\
\hline
\end{tabular}

Source of data: The results of the questionnaire distribution

Based on the results of the frequency distribution table can be seen that utilize the internet as a source of information, it can be seen from the 100 respondents as much as $29.67 \%$ in the 
excellent category, $41 \%$ in both categories, and then as much as $17 \%$ in the category enough, as many as $6,67 \%$ in the unfavorable category, and $5.67 \%$ did not answer. Based on the results of this research is that most college students often use the internet as the need to obtain the information, this is reinforced by the results of a questionnaire that was circulated seberan, this can be seen from the 100 respondents as much as $70.67 \%$ in the excellent category, and the category of good, as much as $17 \%$ in the category enough and as much as $6.67 \%$ unfavorable. Based on the findings and interviews from the above opinion can be concluded that students IAIN Kendari to information obtained from the colleges select Internet media. Can be seen from the table each school year since the development of Kendari IAIN stew with various applications display can show the results of a significant number of year-to year the number of students who choose these colleges increases every year.

\section{The progress of students in Diagram}

The progress of students in the Faculty of Tarbiyah and Science Teaching Diagram IAIN Kendari

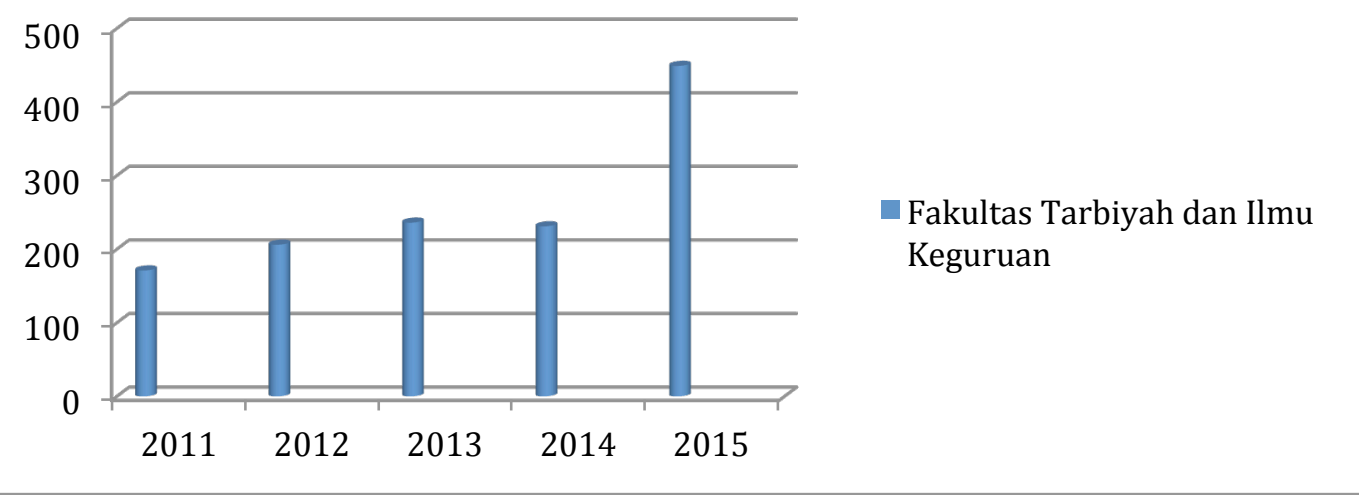

Source of data: The Academic IAIN Kendari

The progress of students in the Faculty of Sharia IAIN Diagram IAIN Kendari

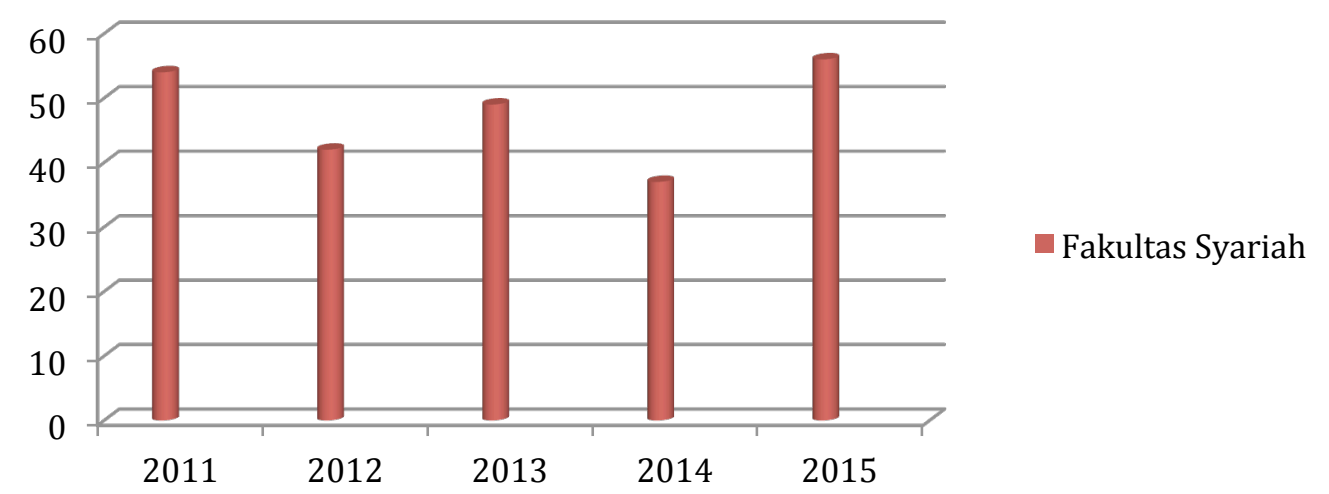

Source of data: The Academic IAIN Kendari 
The progress of students in the Faculty of Ushuluddin and Da'wah of Adab Diagram IAIN Kendari

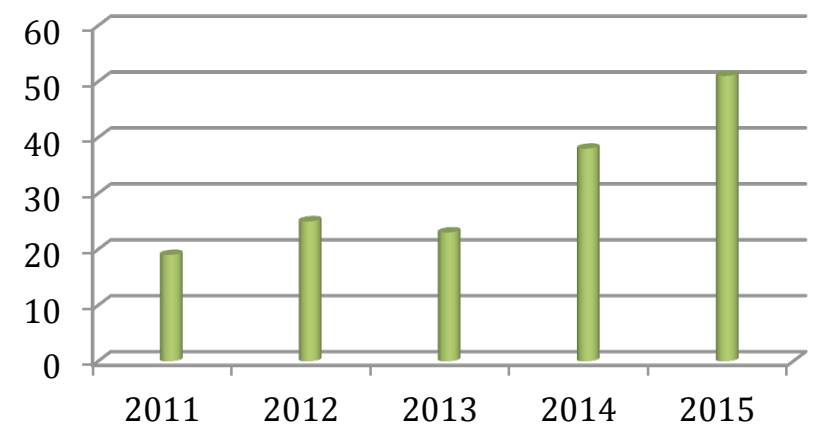

Fakultas Ushuluddin Adab dan Dakwah

Source of data: The Academic IAIN Kendari

The progress of students in the Faculty of Banking and Business Islam Diagram IAIN Kendari

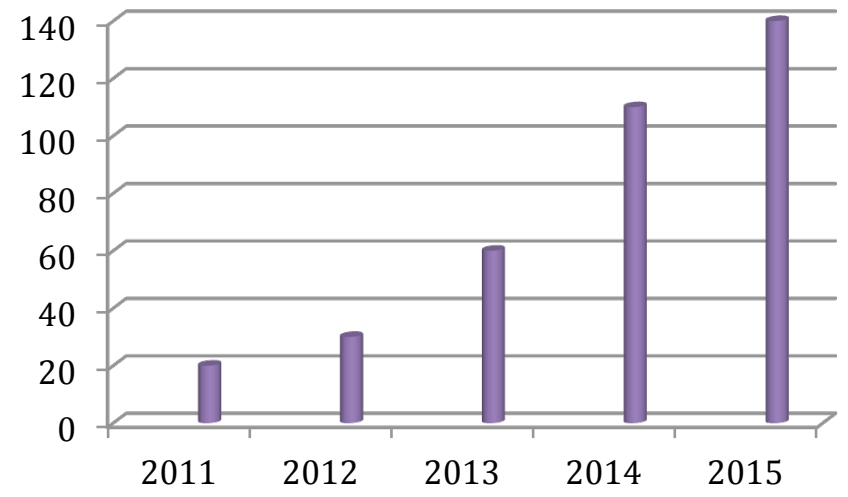

- Fakultas Perbankan dan Bisnis

Source of data: The Academic IAIN Kendari

The progress of the Graduate Students in Diagram IAIN Kendari

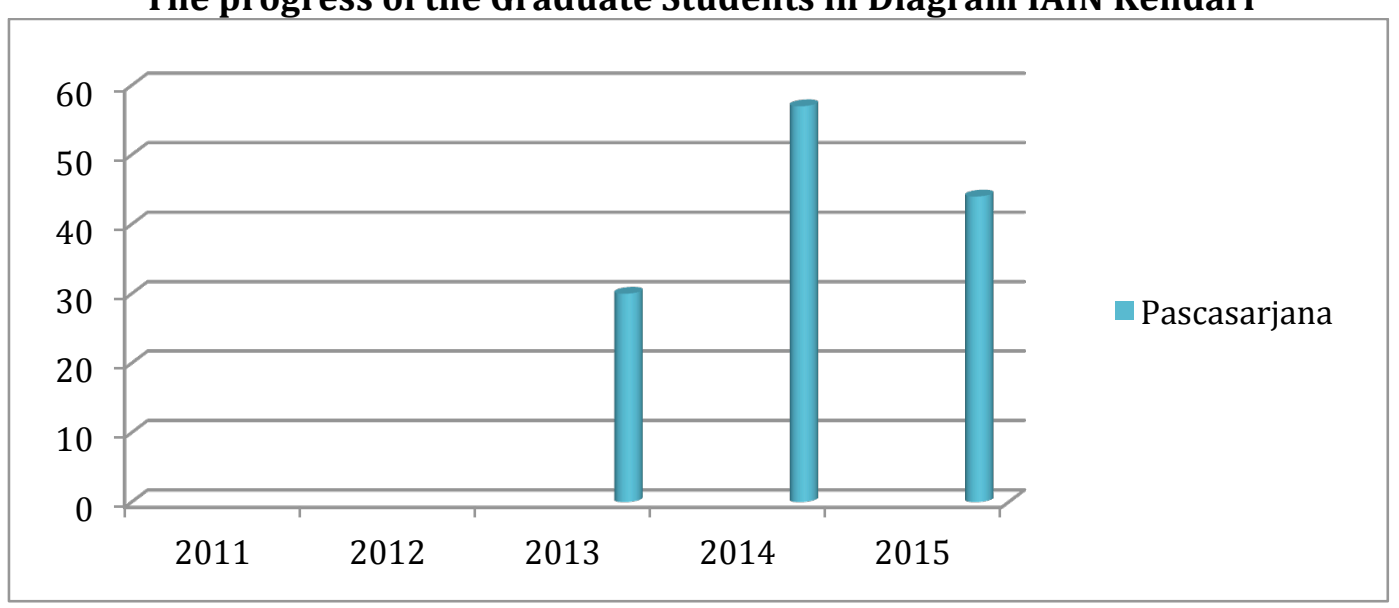

Source of data: The Academic IAIN Kendari 
The progress of students in the All Faculty Diagram IAIN Kendari

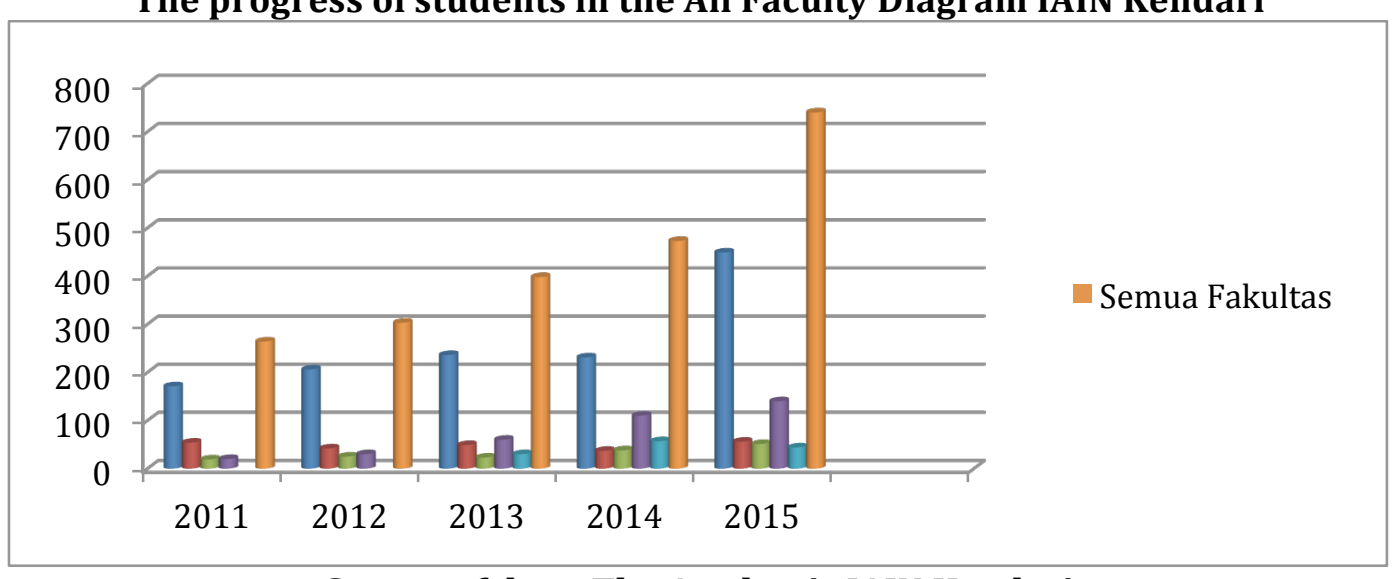

Source of data: The Academic IAIN Kendari

Number of Students IAIN Kendari Developments in Each Year

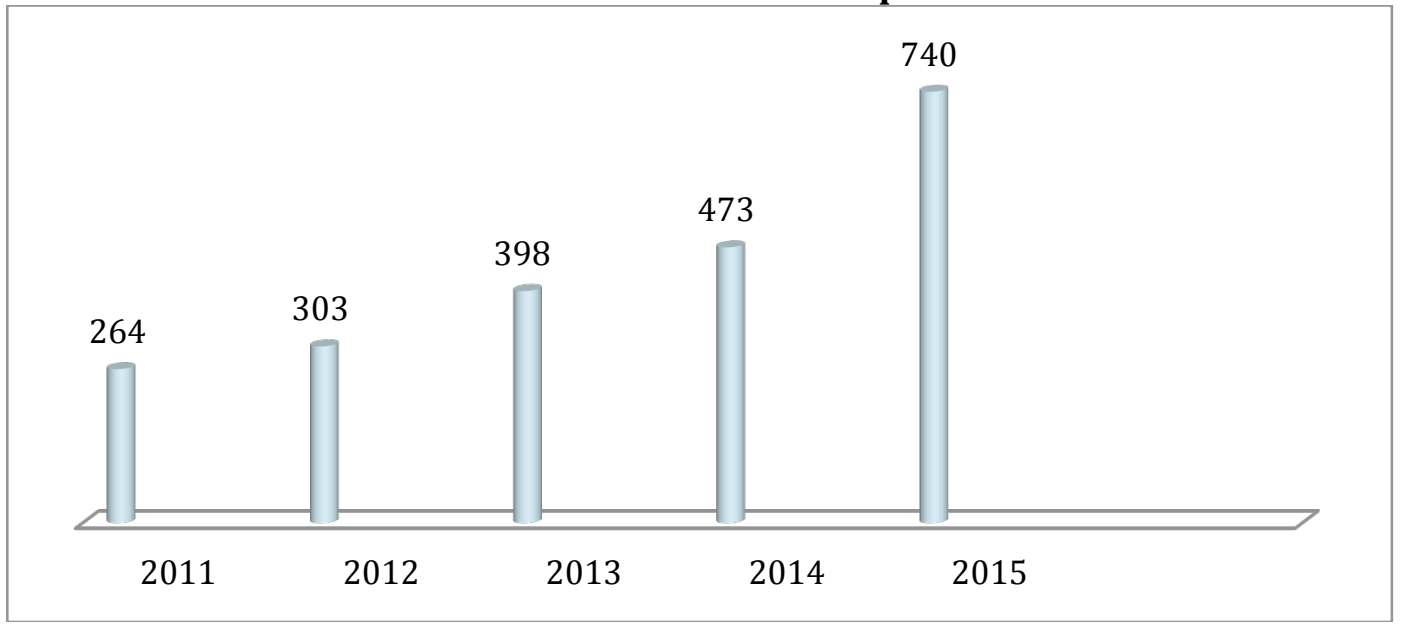

Source of data: The Academic IAIN Kendari

It can be concluded that the effectiveness of the use of the Internet to spread information that shows the plan can be achieved. The more plans that can be achieved, the more effective the activity, so that effectiveness can also be interpreted as the level of success that can be achieved from a certain way or businesses in accordance with the planned objectives. Effectiveness indicates success if the results of the activities closer to the target, meaning the higher the effectiveness, with regard to the implementation of all the main tasks, achievement of objectives, timeliness, and the active participation of members and is the link between the objectives and results expressed, and shows the degree of correspondence between the objectives expressed with the results achieved showed greater improvement rise achievement.

\section{CONCLUSION}

1. Results of votes on the Internet use of the 100 respondents IAIN Kendari penggunauntuk some application services that are already online between $64 \%$ to $88 \%$ said very well and good, $11 \%$ up to $28 \%$ provided enough votes, and $2 \%$ to $18 \%$ which gives less votes.

2. Difficulties / Obstacles in the implementation of the teaching and learning process by using the Internet in the classroom IAIN Kendari is the Internet network access and the signal is so weak that the implementation for developing a learning is not optimal, this means access to the internet campus facilities can not be used due to an internal technical factors. 
3. Achievement in Internet use in publishing information that shows the plan can be achieved is evidenced by the number of college students who choose IAIN Kendari every year increasing numbers who obtained the information from the website IAIN Kendari start of 2011 s / d by 2015 with average growth rates of each year 435 students / year.

4. The need for the information service center by academicians of IAIN Kendari and digital development primarily diperpustakaan IAIN Kendari, should be anticipated as well to the needs of science and research focus is in the library.

\section{References}

1. Abbas Tashakkori dan Charles Teddlie. (2010). Mixed Methodology: Qualitative and Quantitative Approach Combines, Yogyakarta:Pustaka Pelajar, 29.

2. John W Creswel. (2009). Research Design Approach Qualitative, Quantitative, and Mixed, Yogyakarya: Pustaka Pelajar, 840.

3. Jogiyanto Hartono. (2005). Analysis and Design of Information Systems. Andi. Yogyakarta, 638.

4. John W. Satzinger. (2010). Systems Analysis and Design in a Changing World (with Computing Science and Information Technology CourseMate Printed Access Card)6th. Course Technology Press: Boston,MA,United States, Sutabri, Tata. (2012). Analysis of Information Systems. Andi Offset. Yogyakarta,12.

5. Sugiyono. (2012). Quantitative Research Methods, Qualitative, and R \& D, Bandung: Alfabeta, 27.

6. website:http://iainkendari.ac.id

7. http://www.span-ptkin.ac.id 